\title{
PROBIOTICS AND PREBIOTICS IN THE PREVENTION OF GASTROINTESTINAL ADVERSE REACTIONS RELATED TO DIABETES MELLITUS
}

\author{
ANDRADA COȘOREANU ${ }^{1}$, EMILIA RUSU ${ }^{1,2} *$, FLORIN RUSU ${ }^{3}$, MARIA BĂLEANU $^{4}$, \\ CĂTĂLINA CÎRSTEA ${ }^{1}$, MIHAI MARINESCU ${ }^{4}$, GABRIELA RADULIAN ${ }^{2,5}$ \\ 1 "Nicolae Malaxa” Clinical Hospital, 12 Vergului Road, 022441, Bucharest, Romania \\ 2 "Carol Davila" University of Medicine and Pharmacy, 37 Dionisie Lupu Street, 020021, Bucharest, Romania \\ 3 “Carol Davila” Clinical Emergency Military Hospital, 134 Calea Plevnei, 010825, Bucharest, Romania \\ 4 "CI Parhon" National Institute of Endocrinology, 34-36 Aviatorilor Boulevard, 011863, Bucharest, Romania \\ 5 "Prof. NC Paulescu” National Institute of Diabetes, Nutrition and Metabolic Diseases, 5-7 Ion Movilă Street, 030167, \\ Bucharest, Romania
}

*corresponding author: emiliarusumd@yahoo.com

Manuscript received: May 2020

\begin{abstract}
It is of greatest significance today the extent of how chronic metabolic diseases are connected to the heterogeneity of bacterial dysbiosis. Type 2 Diabetes Mellitus (T2DM) is a major health problem and its prevalence has been considerable over the last years, with approximately 463 million adults suffering from diabetes in 2019, according to the International Diabetes Federation (IDF). Predictions in the $9^{\text {th }}$ edition of the IDF Diabetes Atlas estimate an increased number of 578 million for the next decade. Concern that dysbiosis affects carbohydrate metabolism has emphasized the need to study the relationship between altered flora in the gastrointestinal tract and T2DM. Based on the evidence reviewed, the mechanism has been increasingly attractive and permitted to take into consideration new therapeutical options, such as probiotics and prebiotics in the prevention of gastrointestinal adverse reactions related to diabetes. Therefore, the aim of this article is to assert the association between the pathogenesis of T2DM, its treatment and the promising beneficial role of probiotics and prebiotics in the management of this disease.
\end{abstract}

\section{Rezumat}

De mare actualitate în literatura medicală este gradul legăturii bolilor metabolice cronice cu heterogenitatea disbiozei intestinale. Diabetul zaharat de tip 2 reprezintă o problemă mondială de sănătate, iar prevalența a fost considerabilă în ultimii ani: aproximativ 463 de milioane de adulți suferă de diabet zaharat, conform datelor din anul 2019 ale Federației Internaționale de Diabet. Predicțiile apărute în a IX-a ediție a atlasului Federației Internaționale de Diabet sugerează un număr estimativ de 578 de milioane de pacienți în decada următoare. Implicarea disbiozei intestinale în metabolismul glucidic a evidenţiat nevoia de a studia interacțiunea dintre alterarea florei gastrointestinale și diabetul zaharat de tip 2. Pe baza evidențelor din literatură, mecanismul acestei legături a permis considerarea a unor noi opțiuni terapeutice pentru prevenția reacțiilor adverse gastrointestinale apărute în urma medicației antidiabetice, precum prebioticele și probioticele. Astfel, scopul acestui articol este de a susține relația dintre patogeneza diabetului zaharat de tip 2 și beneficiul promițător al prebioticelor și probioticelor în managementul terapeutic al bolii.

Keywords: bacterial dysbiosis, diabetes mellitus, probiotics, prebiotics

\section{Introduction}

Nowadays, there is no doubt dysbiosis is connected to the development of metabolic conditions, such as obesity, diabetes, dyslipidaemia and cardiovascular disease [1-3]. The metabolic syndrome, which includes obesity, hyperglycaemia, insulin resistance, atherogenic dyslipidaemia and hypertension continues to critically extend, thus the potential role of the intestinal microbiota might provide an answer [4-6].

Overweight and obesity are the result of a disproportion between energy input and energy expenditure that lead to multiple complications, affecting all organ systems of the human body. Genetic and epigenetic factors engaged in the pathophysiology have been related to abnormal intestinal microflora- an essential indicator of the organism-environment metabolic connection [7]. These modifications have been studied on obese mice, evidence showing that the altered flora was mostly represented by Firmicutes and Bacteroidetes. Later analyses in humans certified these changes. [8] Although intestinal microbiota transferred from normoponderal to obese patients might be a beneficial measure currently taken into account, the use of probiotics and prebiotics seems a plausible therapeutic method in the obesity management algorithm [7]. 
At present, dual therapy using statins and probiotics has shown its efficiency in not only atherogenic dyslipidaemia, but also non-alcoholic fatty liver disease (NAFLD) [9].

Consequently, the association between the pathogenesis of T2DM, its treatment and the promising beneficial role of probiotics and prebiotics in the management of this disease have been an area of increasing interest [4].

\section{Biological and metabolic effects of the intestinal microbiota}

The intestinal flora has various biological and metabolic functions. It produces molecular compounds that are pharmacologically active in the metabolism of the host. One example would be short- chain fatty acids (SCFAs), that play an important role in the energy metabolism [10]. These molecules are produced by fermentation of dietary fibres; they transmit signals that interact with $\mathrm{G}$ protein-coupled receptors (GPCRs) GPR41, GPR43 or GPR109A and activate specific pathways involved in the oxidative stress [11].

The three most common known SCFA are the butyric acid, propionic acid and acetic acid. The butyrate provides energy for the colonic epithelium that can intensify the mitochondrial activity; it also reduces endotoxins and activates the intestinal gluconeogenesis through a cAMP pathway [12]. The propionate stimulates the hepatic lipogenesis and gluconeogenesis, while the acetate is involved in the peripheral synthesis of cholesterol [13].

The intestinal flora is also involved in the proteic metabolism. It has been established the fact that the colonic microbiota has an important proteolytic activity. Exogenous, as well as endogenous proteins are transformed into short peptides, aminoacids, fatty acids and gases. The bacteria involved are Clostridia, Streptococci, Staphylococci and Bacillus species [12]. Studies have asserted the gut microbiota's implication in the vitamin synthesis: vitamin $\mathrm{K}$ and $\mathrm{B}$ group vitamins - thiamine (B1), riboflavin (B2), niacin (B3), panthotenic acid (B5), pyridoxine (B6), biotin (B7), folic acid (B9) and cobalamin (B12) [12].

The commensal bacteria have an impact on the intestinal hormones release, as well. The metabolites produced transmit signals to the specialized enteroendocrine cells, causing the release of hormones such as cholecystokinine (CCK), peptide YY (PYY), glucagonlike-peptide-1 (GLP-1), gastric inhibitory polypeptide (GIP) and 5-hydroxytryptamine (5-HT) [14].

\section{Probiotics and prebiotics}

According to the World Health Organisation, probiotics are described as living microorganisms similar to the ones naturally colonizing the intestinal ecosystem with beneficial effects on the host when administered in the right amounts [15]. The most frequently available are the Lactobacillus and Bifidobacterium genera and the fungus Saccharomyces boulardii [16]. Over the last few years, results of clinical studies have shown that administration of probiotic products has a variety of desirable effects, from alleviating gastrointestinal symptoms such as meteorism, flatulence, constipation, diarrhoea or abdominal pain to modulating the normal function of the small intestine immune system [17]. Lactobacillus and Bifidobacter species modulate tissular composition of fatty acids; they can form bioactive isomers of the linoleic acid having immunological functions, reducing proinflammatory cytokines $[10,13]$.

Recent data illustrated the effect of probiotics in reducing plasma glucose and improving $\mathrm{HbA1c}$, albeit by a modest degree. The average reduction of glycaemia was $-26.3 \mathrm{mg} / \mathrm{dL}(-1.46 \mathrm{mmol} / \mathrm{L})$, whilst the reduction of $\mathrm{HbA} 1 \mathrm{c}$ values did not exceed $0.32 \%$. Some reviews also suggested a reduction in the HOMA-IR [18]. Other clinical trials asserted an improvement in inflammatory parameters, with lower concentrations of TNF- $\alpha$, resistin and IL-10 [19].

Regarding the prebiotics, they are defined as a group of non-digestible compounds that stimulate the growth of beneficial intestinal bacteria [20]. There are a variety of categories of prebiotics; most of them are fructo-, galacto- or malto-oligosaccharide carbohydrates (OSCs), cyclodextrins and lactosaccharose. They represent an energy source for the intestinal microorganisms that modulates their function. Prebiotics are fermented in the lower segments of the digestive tract, this transformation leading to an increased production of SCFAs, a decreased production of nitrous end products and enzymes [21].

On the grounds that probiotics, as well as prebiotics may play an important role in maintaining the balance of the intestinal microbiota, they have been intensely explored in current clinical practice of T2DM.

\section{Modified microbiota in patients with T2DM}

The human intestinal tract includes a plentiful group of bacteria, viruses considered to be fundamental not only to environmentally-induced conditions, but also to the normal functions of human body [22]. With reference to T2DM, it is accepted the fact that these patients have a different composition of the gut microbiota.

Thus, Bifidobacteria and Akkermansia muciniphilia are found in small amounts, whereas Enterococci, Escherichia coli, Lactobacillus gasseri, Streptococcus mutans, Proteobacteria, certain Clostridiales and Firmicutes are significantly higher [23, 24]. Metabolites produced by these gut microbes are related to detrimental metabolic effects on glucose homeostasis and insulin resistance in T2DM [14]. One of the mechanisms suggested is that lipopolysaccharides (LPS), gut-derived endotoxins might be implied [1]. 
LPS initiate the immune response by binding to the CD14-TLR4 (CD14 toll-like receptor 4), with cytokine secretion and proliferation leading to systemic chronic inflammation found in T2DM [10, 13]. Consequently, this chronic inflammatory status activates the immune system, contributing to excess lipid accumulation, impaired insulin sensitivity and metabolic diseases [11]. Studies showed that higher levels of LPS are connected to an earlier onset of diabetes, increased triglyceride levels, higher blood pressure; moreover, associated with lower HDL concentration, they enhance the cardiovascular risk [25].

Bariatric surgery (Roux-en-Y gastric bypass) used for weight loss in T2DM patients with morbid obesity was outlined with an increase in Proteobacteria and a decrease in Firmicutes and Bacteroidetes [26].

\section{Implications of current therapeutic options in T2DM}

\section{Metformin}

Metformin is most well-known for interacting with the gut microbiome. Since its discovery, metformin has been the first line medication in the treatment algorithm of T2DM. 30\% of patients have gastrointestinal adverse effects that might lead to poor compilation and discontinuation of the treatment. One of the hypotheses formulated suggests the alteration of folate production bacteria, which can impair the gastrointestinal tract balance. Metformin might suppress their growth and cause these adverse reactions.

Some probiotics specifically designed to stimulate the production of folate (also known as vitamin B9) in the digestive tract might help alleviate metforminrelated gastrointestinal adverse reactions and increase therapeutical compliance to metformin [27].

Moreover, some authors suggested that a modulation of the gut microbiota (likely an increase in the Akkermansia spp. population) and an increased production of SCAFs may contribute to the glucose-lowering effects of metformin [23, 28].

Acarbose

Another glucose-lowering medication used in T2DM is acarbose, an $\alpha$-glucosidase inhibitor. This drug has effects that could be connected to the intestinal flora. Studies revealed that acarbose might increase faecal Bifidobacterium spp. and reduce the levels of lipopolysaccharides (LPS) [29].

Glucagon-like peptide 1 receptor agonist

Further insights focus on the fact that probiotics could affect the structure of gut flora, enhance GLP-1 secretion from enteroendocrine L-cells to improve carbohydrate metabolism, and increase insulin sensitivity of target cells [30, 31].

Glucagon-like peptide 1 (GLP-1) is an incretin hormone made of a complex of 30-amino acids formed in the ileal and colonic epithelial L-cells, part of the enteroendocrine system, having multiple actions on alfa and beta pancreatic cells, gastrointestinal tract, central nervous system and the heart. GLP-1 effects are mediated by its specific receptors, activating multiple pathways that include adenylyl cyclase, intracellular accumulation of cyclic adenosine monophosphate, activation of protein kinase $\mathrm{A}$, increase in intracellular calcium and thus stimulating the secretion of insulin [30]. The insulin secretion is dependent on the level of plasmatic glucose. GLP1 also inhibits gastric emptying, supresses appetite and reduces body weight. Some products of microbial fermentation, for example short chain fatty acids (SCFAs) found in prebiotics can stimulate the release of GLP-1 and contribute to glycaemic homeostasis [30, 32, 33]. Data collected from experiments of liraglutide on diabetic male rats emphasize the modifications specified: it raises the levels of SCFA producing bacteria, such as Bacteroides, Lachnospiraceae and probiotic bacteria, including Bifidobacterium [34].

\section{Conclusions}

For the aforementioned reasons, there cannot be denied the high complexity of the intestinal microbiota-brain axis, although their functional connections are still a matter of debate. The interaction between the gut microbiota and the neuroendocrine system confers a normal control of digestion, absorption, insulin secretion and there are expected future studies to reveal the effectiveness of these pursued preventive measures using prebiotics and probiotics.

\section{Conflict of interest}

The authors declare no conflict of interest.

\section{References}

1. Tilg H, Moschen AR, Microbiota and diabetes: an evolving relationship. Gut, 2014; 63(9): 1513-1521.

2. IDF Diabetes Atlas, $9^{\text {th }}$ Edition Committee 2019; ISBN: 978-2-930229-87-4; www.diabetesatlas.org.

3. Hartstra AV, Bouter KE, Bäckhed F, Nieuwdorp M, Insights into the role of the microbiome in obesity and type 2 diabetes. Diabetes Care, 2015; 38(1): 159-165.

4. Tonucci LB, Olbrich Dos Santos KM, Licursi de Oliveira L, Rocha Ribeiro SM, Duarte Martino HS, Clinical application of probiotics in type 2 diabetes mellitus: A randomized, double-blind, placebo-controlled study. Clin Nutr., 2017; 36(1): 85-92.

5. Wen L, Duffy A, Factors influencing the gut microbiota, inflammation, and type 2 diabetes. J Nutr., 2017; 147(7): 1468S-1475S.

6. Becheanu CA, Tुincu IF, Smădeanu RE, Coman OA, Coman L, Ţincu RC, Păcurar D, Benefits of oligofructose and inulin in management of functional diarrhoea in children - interventional study. Farmacia, 2019; 67(3): 511-516.

7. Caramoci A, Vasilescu M, Nica AS, Pop M, Rosulescu E, Mirela Ionescu A, Potential pharmaceutical uses 
of probiotics and prebiotics in obesity management. Farmacia, 2017; 65(5): 667-676.

8. Ferrer M, Ruiz A, Lanza F, Haange SB, Oberbach A, Till H, Bargiela R, Campoy C, Segura MT, Richter M, von Bergen M, Seifert J, Suarez A, Microbiota from the distal guts of lean and obese adolescents exhibit partial functional redundancy besides clear differences in community structure. Environ Microbiol., 2013; 15(1): 211-226.

9. Zvenigorodskaia LA, Cherkashova EA, Samsonova NG, Nilova TV, Sil'verstova SI, Advisability of using probiotics in the treatment of atherogenic dyslipidemia. Eksp Klin Gastroenterol., 2011; 2: 37-43, (available in Russian).

10. Rusu E, Enache G, Cursaru R, Alexescu A, Radu R, Onila O, Cavallioti T, Rusu F, Posea M, Jinga M, Radulian G, Prebiotics and probiotics in atopic dermatitis. Exp Ther Med., 2019; 18(2): 926-931.

11. Boulangé CL, Neves AL, Chilloux J, Nicholson JK, Dumas ME. Impact of the gut microbiota on inflammation, obesity, and metabolic disease. Genome Med., 2016; 8: 1-12.

12. Rowland I, Gibson G, Heinken A, Scott K, Swann J, Thiele I, Tuohy K, Gut microbiota functions: metabolism of nutrients and other food components. Eur J Nutr., 2018; 57(1): 1-24.

13. Scheppach W, Effects of short chain fatty acids on gut morphology and function. Gut, 1994; 35(1 Suppl): S35-S38.

14. Martin AM, Sun EW, Rogers GB, Keating DJ, The influence of the gut microbiome on host metabolism through the regulation of gut hormone release. Front Physiol., 2019; 10: 1-11.

15. Mack DR, Probiotics-mixed messages. Can Fam Physician., 2005; 51(11): 1455-1457.

16. Fijan $\mathrm{S}$, Microorganisms with claimed probiotic properties: An overview of recent literature. Int $J$ Environ Res Public Health, 2014; 11(5): 4745-4767.

17. Zhang Q, Wu Y, Fei X, Effect of probiotics on glucose metabolism in patients with type 2 diabetes mellitus: A meta-analysis of randomized controlled trials. Medicina, 2016; 52(1): 28-34.

18. Sun J, Buys NJ, Glucose-and glycaemic factor-lowering effects of probiotics on diabetes: a meta-analysis of randomised placebo-controlled trials. $\mathrm{Br} J \mathrm{Nutr}$., 2016; 115(7): 1167-1177.

19. Tonucci LB, Olbrich dos Santos KM, Licursi de Oliveira L, Rocha Ribeiro SM, Duarte Martino HS, Clinical application of probiotics in type 2 diabetes mellitus: A randomized, double-blind, placebo-controlled study. Clin Nutr., 2017; 36(1): 85-92.

20. Davani-Davari D, Negahdaripour M, Karimzadeh I, Seifan M, Mohkam M, Masoumi SJ, Berenjian A, Ghasemi Y, Prebiotics: Definition, types, sources, mechanisms, and clinical applications. Foods, 2019; 8(3): 1-27.

21. Andrei AM, Berbecaru-Iovan A, Felix Din-Anghel RI, Binişor ID, Marinescu RM, Goga LD, Baniță IM, Pisoschi CG, New insights into brown adipose tissue as a pharmacological target in obesity. Farmacia, 2020; 68(1): 1-7.
22. Tilg H, Moschen AR, Microbiota and diabetes: An evolving relationship. Gut, 2014; 63(9): 1513-1521.

23. Shin NR, Lee JC, Lee HY, Kim MS, Whon TW, Lee MS, Bae JW, An increase in the Akkermansia spp. population induced by metformin treatment improves glucose homeostasis in diet-induced obese mice. Gut, 2014; 63(5): 727-735.

24. Grigorescu I, Dumitrascu DL, Implication of gut microbiota in diabetes mellitus and obesity. Acta Endocrinol., 2016; 12(2): 206-214.

25. Lassenius MI, Pietiläinen KH, Kaartinen K, Pussinen PJ, Syrjänen J, Forsblom C, Pörsti I, Rissanen A, Kaprio J, Mustonen J, Groop PH, Lehto M; FinnDiane Study Group, Bacterial endotoxin activity in human serum is associated with dyslipidemia, insulin resistance, obesity, and chronic inflammation. Diab Care, 2011; 34(8): 1809-1815.

26. Graessler J, Qin Y, Zhong H, Zhang J, Licinio J, Wong ML, Xu A, Chavakis T, Bornstein AB, Ehrhart-Bornstein M, Lamounier-Zepter V, Lohmann T, Wolf T, Bornstein $\mathrm{SR}$, Metagenomic sequencing of the human gut microbiome before and after bariatric surgery in obese patients with type 2 diabetes: Correlation with inflammatory and metabolic parameters. Pharmacogenom J., 2013; 13(6): 514-522.

27. Olgun A, "Metformin-resistant" folic acid producing probiotics or folic acid against metformin's adverse effects like diarrhea. Med Hypotheses, 2017; 106: 33-34.

28. Wu H, Esteve E, Tremaroli V, Khan MT, Caesar R, Mannerås-Holm L, Ståhlman M, Olsson LM, Serino M, Planas-Fèlix M, Xifra G, Mercader JM, Torrents D, Burcelin R, Ricart W, Perkins R, Fernàndez-Real JM, Bäckhed F, Metformin alters the gut microbiome of individuals with treatment-naive type 2 diabetes, contributing to the therapeutic effects of the drug. Nat Med., 2017; 23(7): 850-858.

29. Delzenne NM, Cani PD, Everard A, Neyrinck AM, Bindels LB, Gut microorganisms as promising targets for the management of type 2 diabetes. Diabetologia, 2015; 58(10): 2206-2217.

30. Holst JJ, The physiology of glucagon-like peptide 1 . Physiol Rev., 2007; 87(4): 1409-1439.

31. MacDonald PE, El-kholy W, Riedel MJ, Salapatek AMF, Light PE, Wheeler MB, The multiple actions of GLP-1 on the process of glucose-stimulated insulin secretion. Diabetes, 2002; 51(Suppl 3): S434-S442.

32. Tolhurst G, Heffron H, Lam YS, Parker HE, Habib AM, Diakogiannaki E, Cameron J, Grosse J, Reimann F, Gribble FM, Short-chain fatty acids stimulate glucagon-like peptide-1 secretion via the G-proteincoupled receptor FFAR2. Diabetes, 2012; 61(2): 364-371.

33. Gribble FM, Reimann F, Function and mechanisms of enteroendocrine cells and gut hormones in metabolism. Nat Rev Endocrinol., 2019; 15(4): 226-237.

34. Zhang Q, Xiao X, Zheng J, Li M, Yu M, Ping F, Wang T, Wang X, Featured article: Structure moderation of gut microbiota in liraglutide-treated diabetic male rats. Exp Biol Med., 2018; 243(1): 34-44. 